\title{
INVENTORY OF AMMONIA EMISSIONS FROM LIVESTOCK PRODUCTION IN LOS LAGOS AND LOS RÍOS REGIONS, CHILE
}

\author{
Josué Martínez-Lagos ${ }^{1}$, Francisco Salazar ${ }^{1 *}$, Marta Alfaro ${ }^{1}$, and Tom H. Misselbrook ${ }^{2}$
}

\begin{abstract}
This paper presents the first inventory of ammonia emissions from livestock production in Los Lagos and Los Ríos Regions of Chile. The inventory was focused in this area because is where cattle production is concentrated. This study aimed to quantify the amount of $\mathrm{N}$ losses due to ammonia volatilization from livestock production in these regions of the country, and to provide its spatial representation identifying their main sources. Calculations have been carried out for 1997 and 2007, and also projections to 2017 and 2027 were obtained. Calculated emissions were 6097 and $6206 \mathrm{t} \mathrm{NH}_{3}-\mathrm{N}$ for 1997 and 2007, respectively. Major sources of $\mathrm{NH}_{3}-\mathrm{N}$ emissions were cattle accounting for more than $85 \%$, followed by horses and pigs. Farm management practices as grazing, housing, manure storage and land spreading of manure accounted for $87 \%, 9 \%, 3 \%$, and 2\%, respectively, of total annual emissions. Projections suggest that emissions could increase up to 6344 and $6516 \mathrm{t} \mathrm{NH}_{3}-\mathrm{N}$ for 2017 and 2027, respectively. Emissions are much lower than those reported for developed European countries. However, intensification of cattle production systems may lead to an increase of ammonia emissions which could impact the temperate forest of Southern Chile characterized by low nutrient fluxes.
\end{abstract}

Key words: ammonia, inventory, livestock production, emissions.

\section{INTRODUCTION}

Ammonia $\left(\mathrm{NH}_{3}\right)$ is a gas, among other emission sources, product of animal waste due to an inefficient conversion of the feed $\mathrm{N}$ into animal products. The not metabolized $\mathrm{N}$ is excreted in the urine and faeces of livestock, where microbial activity releases $\mathrm{NH}_{3}$ during the decomposition of these excretal materials (Sommer et al., 2004). These $\mathrm{N}$ losses through $\mathrm{NH}_{3}$ volatilization from animal activities reduce the efficient use of this nutrient and can cause the indirect increase of other gases emissions like nitrous oxide $\left(\mathrm{N}_{2} \mathrm{O}\right)$ in the atmosphere (Eckard et al., 2003). On a global scale, agricultural activity is the major source of $\mathrm{NH}_{3}$ emissions released into atmosphere (Bouwman et al., 1997), and those emissions have doubled over the last century across Europe (Asman et al., 1998). Therefore, $\mathrm{NH}_{3}$ emissions have recently received significant attention and most of the environment concerns related to animal agriculture issues have focused on this important pollutant (Hyde et al., 2003).

The dominant source of agricultural ammonia

'Instituto de Investigaciones Agropecuarias INIA, Casilla 24-0, Osorno, Chile. "Corresponding author (fsalazar@inia.cl).

${ }^{2}$ North Wyke Research, Okehampton, Devon, EX20 2SB, United Kingdom.

Received: 28 November 2008.

Accepted: 25 May 2009. emissions is livestock manure; losses can occur during grazing, housing, manure storage and application. Besides those practices, other important source is the direct volatilization of mineral fertilizers (e.g. urea and ammonium nitrate) applied to pastures or crops (Diaz et al., 2003). The amount of $\mathrm{NH}_{3}$ emissions depends of many factors such as the type of animals, their weight and age, the composition of animal feed, time and type of animal housing and manure storage, method of waste application, type and amount of used organic and inorganic fertilizer, meteorological conditions, soil conditions and regulation of agricultural practices (Hutchings et al., 2001).

Atmospheric ammonia has been linked to various negative effects on ecosystems, such as acidification, eutrophication, acid rain, loss of diversity, and also impacts on human health (Kurvits and Marta, 1998; Jones et al., 2000). In the atmosphere $\mathrm{NH}_{3}$ can react with other pollutants (e.g. $\mathrm{SO}_{2}$ and $\mathrm{NO}_{\mathrm{x}}$ ) to produce acid aerosols and particulate matter like fine ammonium $\left(\mathrm{NH}_{4}^{+}\right)($Diaz et al., 2003). While the lifetime of $\mathrm{NH}_{3}$ is relatively short and can be transferred less than $100 \mathrm{~km}, \mathrm{NH}_{4}{ }^{+}$can be moved longer distances (Asman et al., 1998). Impacts can occur on both local and international scales, and emissions can contribute to international transboundary air pollution; this has been addressed by the United Nations Economic Commission for Europe (UNECE) Convention on Long Range Transboundary Pollution (Hyde et al., 2003). 
During this convention, a "Protocol to Abate Acidification, Eutrophication, and Ground-level Ozone" was set in 1999 (Giles, 2002). This document, known as Gothenburg Protocol, established recommendations for the direct reduction of $\mathrm{NH}_{3}$ emissions by 2010 using data of 1990 emissions as a base line year. Through emissions inventories, member countries like Switzerland, United Kingdom (UK), Ireland and Denmark, have reported their emission values (Hutchings et al., 2001; Hyde et al., 2003; Reidy et al., 2007; Misselbrook et al., 2007). In Chile there is no published national $\mathrm{NH}_{3}$ emission inventory yet, even though livestock production is an important activity in the national economy. Livestock production is based principally in dairy and beef production with a national herd size in 2007 of 3.7 million cattle. Los Lagos and Los Ríos Regions are located in southern Chile and have around 1.6 million cattle producing $70 \%$ of the country's milk and $50 \%$ of the meat (INE, 2007).

In recent years animal production systems in the south of the country have intensified through the increased of the regional livestock numbers (INE, 1997; 2007). This change has made more intensive the land use, and increased the animal burden and the use of inorganic and organic fertilizers (Alfaro and Salazar, 2005). Among organic fertilizers, dairy slurry is the most widely used and its application is estimated to increase in the next years (Salazar et al., 2003), for that reason $\mathrm{NH}_{3}$ emissions trends can be estimated to increase accordingly. These $\mathrm{N}$ losses could be associated with direct and diffuse pollution, which represent a great risk for the environment and the regional natural resources quality (Alfaro and Salazar, 2005).

Estimations of ammonia emissions are then an important tool to determine $\mathrm{N}$ fluxes from the soil to the air (Sommer et al., 2004) and to control the atmospheric emissions from animal agricultural activities (Reidy et al., 2007). Inventories allow to identify the sources of emission, to design suitable management measurements, and to evaluate producer's actions, which always are under pressure to minimize the impacts of their agricultural management practices in the ecosystem (e.g. Kurvits and Marta, 1998; Hutchings et al., 2001; Misselbrook et al., 2007). The aim of this study was to quantify the amount of $\mathrm{N}$ losses due to ammonia volatilization from animal production in Los Lagos and Los Ríos Regions of Chile, and to provide its spatial representation identifying their main sources.

\section{MATERIALS AND METHODS}

The study was carried out taking into account a period of $10 \mathrm{yr}$ (comparing between 1997 and 2007), establishing projections of the estimated results to 20 and $30 \mathrm{yr}$ from the base year. This $\mathrm{NH}_{3}-\mathrm{N}$ inventory was focused in the Los Lagos ( $40^{\circ} 13^{\prime}$ and $\left.44^{\circ} 3^{\prime} \mathrm{S}, 71^{\circ} 34^{\prime} \mathrm{W}\right)$ and Los Ríos ( $39^{\circ} 16^{\prime}$ and $40^{\circ} 4^{\prime} \mathrm{S}$, and $71^{\circ} 35^{\prime} \mathrm{W}$ ) Regions, because this area concentrate Chilean cattle production (Anrique, 1999). Ammonia emission for 1997 was calculated for the former territory of the Region of Los Lagos $\left(39^{\circ}-42^{\circ} \mathrm{S}\right.$ ) with five provinces and 42 districts, while 2007 emissions were estimated for the current Regions of Los Ríos and Los Lagos which area are make up by two provinces and 20 districts, and four provinces and 30 districts, respectively.

The livestock classes included in the inventory were cattle (dairy and beef cows, dairy and beef heifers, dairy and beef calves, steers, bulls, oxen and others), sheep, pigs, equines, goats, and South American camelids. The estimation values determined in the study take into account emissions from farm animals during grazing and housing, and other practices like manure storage and land applications. The numbers of each class of livestock were obtained from the National Survey for Agriculture and Forestry carried out by the Instituto Nacional de Estadística (INE, 1997; 2007). Another values like farm size, percentage of each class of cattle, days of housing and grazing in the study area, quantity of generated effluents, percentages of application to land, and other important information was obtained from scientific literature (e.g. Anrique, 1999; Salazar et al., 2003) and statistics data of the Oficina de Estudios y Políticas Agrarias (ODEPA) and Instituto de Investigaciones Agropecuarias INIA. Also, because of the lack of published statistical information at regional level, expert judgments were used in some cases.

For this study, poultry was no taken into account because there is not published information about number of animals or production system in the area of study. In addition, for deer, rabbits, and wild boars there is no published emission factors for this animal classes, and the animal number in the regions is low. Also, emissions from crops and mineral fertilizers were not calculated because of the lack of fine statistical scientific information like amount or type of fertilizers applied to arable and grasslands. Additionally, livestock numbers and their growth rate used for the predictions are based on the 1997 data, and emission factors and manure management practices were assumed to be the same for all modeled years.

The development of the emission inventories for 1997 and 2007 was adapted from on a multi steps procedure suited on an extended empirical $\mathrm{N}$ mass-flow model. In the original model, the emissions for five livestock categories and four management practices was calculated using emission factors given in terms of $\mathrm{NH}_{3}-\mathrm{N}$. These emission factors derived primarily from measurements in the UK and also estimates from literature where measurements were not available (Misselbrook et al., 
2000). In this approach, in order to generate the procedure input data for each animal category, the first step was the selection of the suitable $\mathrm{NH}_{3}-\mathrm{N}$ emission factors for specific livestock categories, for which most of the British ones were chosen.

The selection of UK emission factors is mainly because there were not available emission factors derived from Chilean conditions, and also because of similar climatic conditions and cattle production systems of the south of Chile and the south west of the UK, where most of the emission factors have been generated (Table 1). Step two consisted in secure accurate survey data, using representative and stratified statistics of the animal numbers for geographic unity (province and district of each region), productive management systems, frequent farm practices and other influencing data relevant for $\mathrm{NH}_{3}-\mathrm{N}$ emissions calculation.

Afterward, a numerical combination in a spreadsheet (Excel, 2007) of the input data generated in the previous steps provided the estimations of $\mathrm{NH}_{3}-\mathrm{N}$ quantity by multiplying the emission factors with the relevant livestock numbers per geographical unities and the other appropriate setting data and variables, whose reflects specific management practices in the study areas (step three). In the step four, based on the stock animal data of the National Survey for Agriculture and Forestry 1997 and 2007, the growth rate of the period for each animal type was calculated and used for the construction of the 2017 and 2027 projections input data. Because the lack of statistical information it was not possible to calculate the $\mathrm{NH}_{3}-\mathrm{N}$ emission for all of the years from 1997 to 2007 in order to show the actual pattern of the emission trend over the study period. Thus, there was the assumption that exist a linear trend between these years, and that projections to 2017 and 2027 continue these trends, therefore $\mathrm{NH}_{3}-\mathrm{N}$ emission factors were estimated to be the same.

In the step five, the resulted $\mathrm{NH}_{3}-\mathrm{N}$ estimations were used to prepare the spatial distributions of the emissions by combining the obtained values with georeferenciated images of the study area in ArcView 3.2a (Arcview, 2007). By this way, merging emissions from livestock production and manure management with geographical data of the area resulted in the livestock production $\mathrm{NH}_{3}-\mathrm{N}$ emission inventory for the study regions.

Table 1. Emission factors used for livestock.

\begin{tabular}{|c|c|c|c|c|c|c|c|c|}
\hline \multirow{2}{*}{\multicolumn{2}{|c|}{ Livestock class }} & \multicolumn{7}{|c|}{ Emission factors } \\
\hline & & \multirow{4}{*}{$\begin{array}{c}\text { Grazing } \\
\mathrm{g} \mathrm{N}_{\text {animal }}^{-1} \mathrm{~d}^{-1} \\
16.9\end{array}$} & \multirow{2}{*}{\multicolumn{2}{|c|}{$\begin{array}{c}\text { Housing } \\
\mathrm{g} \mathrm{N} \mathrm{lu}^{-1 \mathrm{a}} \mathrm{d}^{-1}\end{array}$}} & \multirow{2}{*}{\multicolumn{2}{|c|}{$\begin{array}{c}\text { Waste storage } \\
\mathrm{g} \mathrm{N} \mathrm{m}^{-2} \mathrm{~d}^{-1}\end{array}$}} & \multirow{2}{*}{\multicolumn{2}{|c|}{$\begin{array}{l}\text { Land spreading } \\
\% \mathrm{TAN}^{\mathrm{b}} \text { applied }\end{array}$}} \\
\hline & & & & & & & & \\
\hline \multirow[t]{8}{*}{ Cattle } & Cows & & Dairy cubicles & 34.3 & Not crusted & 4.4 & Slurry (based & 15 \\
\hline & & & Dairy litter & 17.2 & $\begin{array}{l}\text { slurry circular } \\
\text { stores or lagooons }\end{array}$ & & on $\% \mathrm{DM})^{\mathrm{c}}$ & \\
\hline & Heifers & 12.3 & & & & & & \\
\hline & Calves & 1.9 & Calves litter & 10.6 & & & & \\
\hline & Steers & 4.7 & Beef cubicles & 34.3 & Solid manure & 2.5 & Solid manure & 76 \\
\hline & Bulls & 4.7 & & & & & & \\
\hline & Oxen & 4.7 & Beef litter & 17.2 & Yard emission $^{\mathrm{d}}$ & 8.3 & & \\
\hline & Others ${ }^{\mathrm{e}}$ & 8.9 & & & & & & \\
\hline \multirow[t]{2}{*}{ Sheep $^{f}$} & Sheep & 0.6 & & & & & & \\
\hline & Lamb & 0.3 & & & & & & \\
\hline Goats & & $0.45^{\mathrm{g}}$ & & & & & & \\
\hline Pigs & & $6.2^{\mathrm{h}}$ & & $23.4^{\mathrm{i}}$ & & & & \\
\hline Equines & & $10.6^{\mathrm{j}}$ & & & & & & \\
\hline Camelids & & $2.0^{\mathrm{k}}$ & & & & & & \\
\hline
\end{tabular}

alu is equivalent to $500 \mathrm{~kg}$ liveweight.

${ }^{\mathrm{b}} \mathrm{TAN}$ content $=$ total ammoniacal $\mathrm{N}$ content.

c DM $<4 \%$.

${ }^{\mathrm{d}} \mathrm{g} \mathrm{N}$ animal ${ }^{-1} \mathrm{~d}^{1}$.

eAverage value obtained from cattle emission factors used to calculate the emissions on farms with less than 50 animals.

fUpland sheep and lamb emission factors.

gAverage value obtained from upland lambs and sheep emission factors.

${ }^{\text {h}}$ Average value obtained from different pig classes emission factors.

${ }^{i}$ Average value obtained from different slatted and straw bedded pigs housing emission factors.

${ }^{j} \mathrm{~kg} \mathrm{NH}_{3}-\mathrm{N}$ animal ${ }^{-1} \mathrm{yr}^{-1}$.

${ }^{k}$ Estimation adjusted for South American camelids from Schmidt-Nielsen et al., 1957. 


\section{RESULTS AND DISCUSSION}

Estimates of ammonia emissions generated in the study area

Total $\mathrm{NH}_{3}$ emissions in the area of study for approximately 2.2 million livestock head were estimated at $6097 \mathrm{t} \mathrm{NH}_{3}-\mathrm{N}$ in 1997 and $6206 \mathrm{t} \mathrm{NH}_{3}-\mathrm{N}$ for 2007 (Table 2). It was possible to see that the main source of $\mathrm{NH}_{3}-\mathrm{N}$ come from cattle production. Based on the growth rate of the first 10 yr period, it is possible to predict an increase in the animal number throughout the next years, so that this livestock type will remain the largest contributor to the emissions in the area over the next $20 \mathrm{yr}$. As a consequence, $\mathrm{N}$ fertilizer applications to grasslands could be predicted to increase accordingly over the same time because cattle production systems in southern Chile are based on pasture, which can be reflected in greater $\mathrm{NH}_{3}-\mathrm{N}$ emission values during grazing.
In 1997, the contribution of total $\mathrm{NH}_{3}-\mathrm{N}$ emission for the Los Lagos Region provinces were: Valdivia, (37\%), Osorno (31\%), Llanquihue (22\%), Chiloé (9\%) and Palena (2\%) (Figure 1). While in 2007, contribution emissions in provinces of Los Lagos and Los Ríos Regions were: Ranco (19\%), Valdivia (18\%), Osorno (31\%), Llanquihue (23\%), Chiloé (8\%) and Palena (2\%) (Figure 2). For both years, Los Lagos Region generated a total input of $63 \%$ while Los Ríos Region accounted only the $37 \%$ of the total $\mathrm{NH}_{3}-\mathrm{N}$ emission of the territory. Total emission percentages estimated for 2007 per districts were: Río Bueno (11\%), Osorno (6\%), Purranque (6\%) and Puerto Octay (5\%). Other districts in the study area were estimated to be less than $5 \%$ of the emission $(\approx 300$ $\mathrm{t} \mathrm{NH}_{3}-\mathrm{N} \mathrm{yr}^{-1}$ ). In comparison with 1997 data (Figure 1), 2007 Osorno emissions showed a reduction of $0.4 \%$, while the other three districts reached greater values. Emissions from other districts remained less than 5\% of the total estimation.

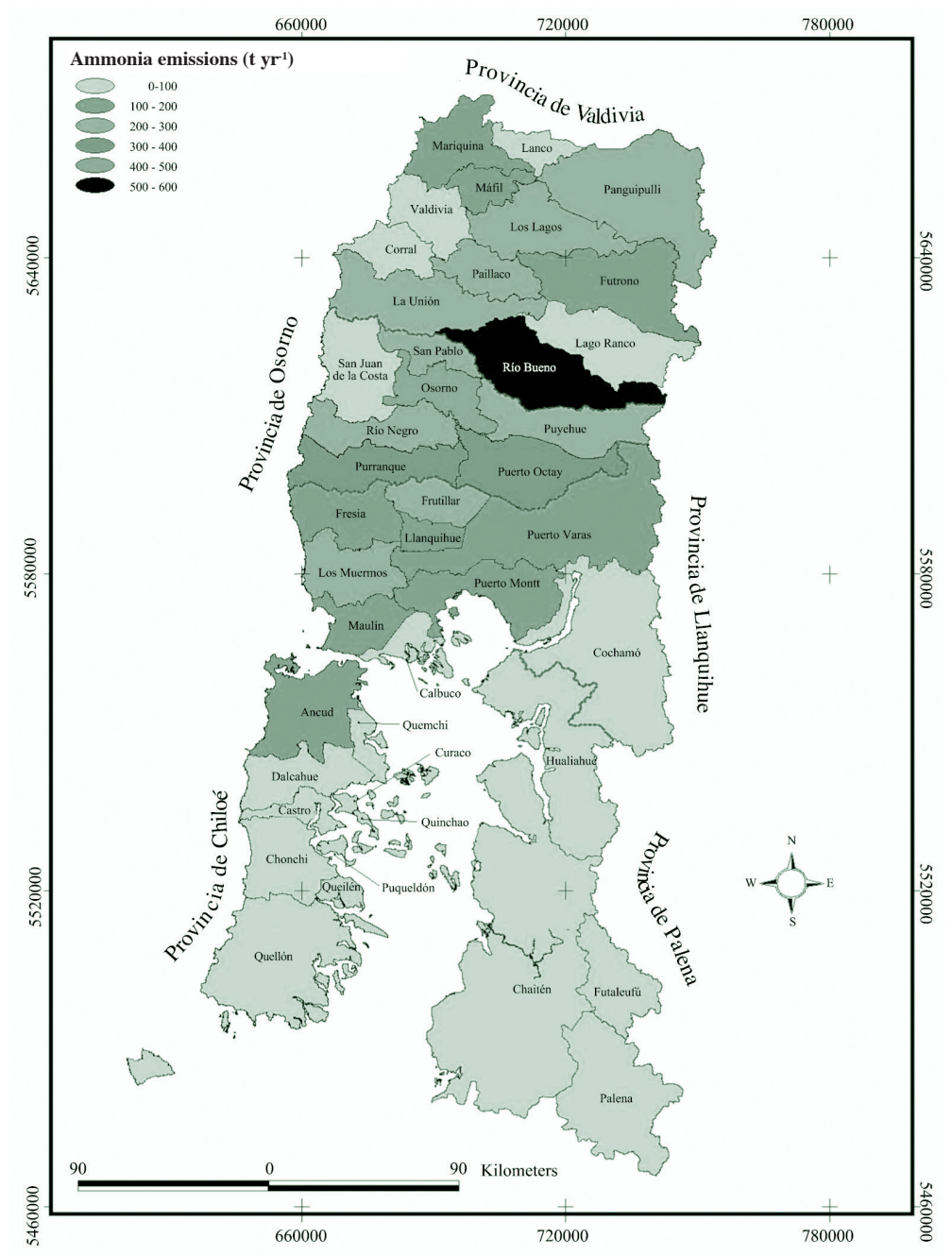

Figure 1. Estimated distribution of $\mathrm{NH}_{3}$ emissions (t) for Los Lagos Region and Los Ríos Regions, Chile, 1997. 


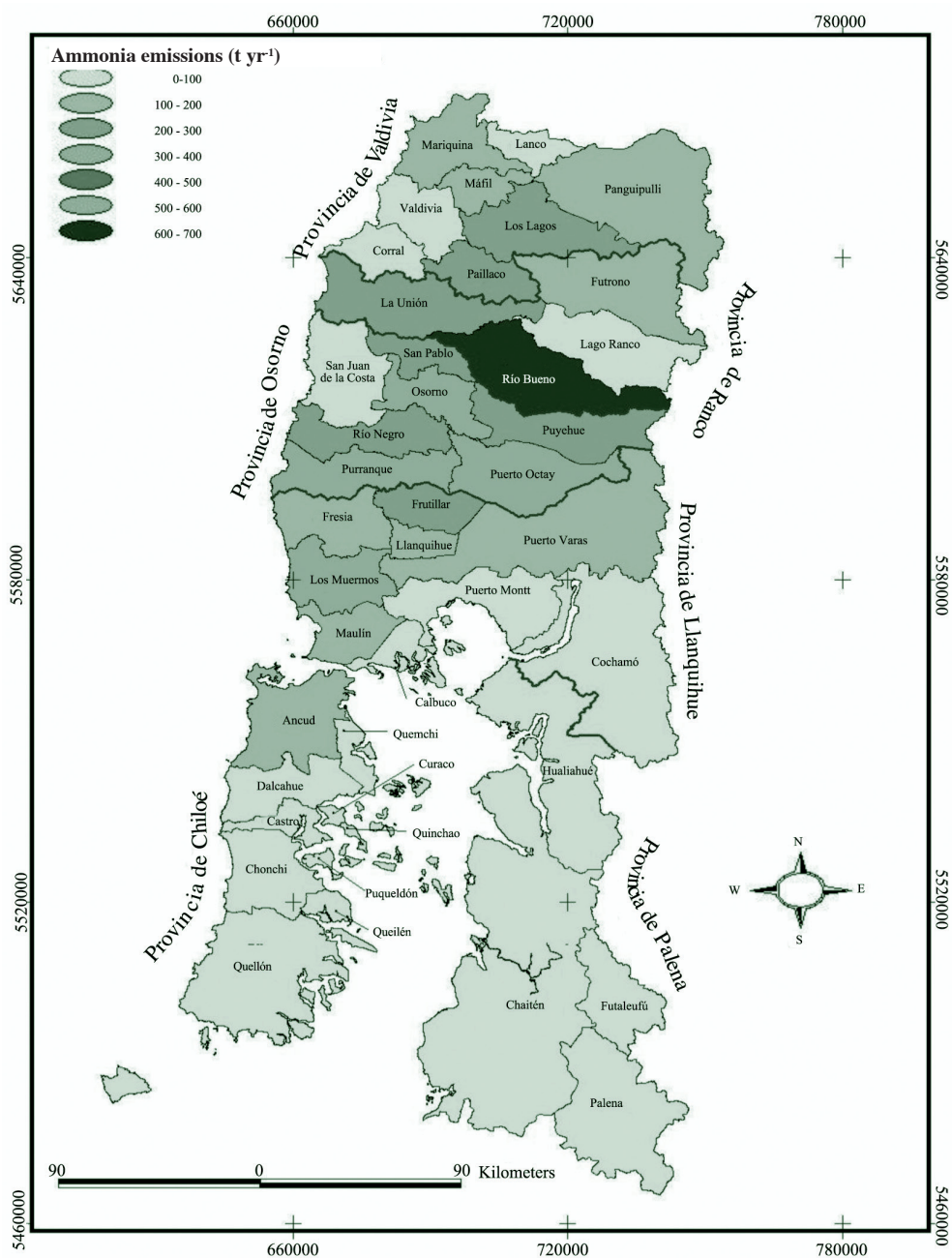

Figure 2. Estimated distribution of $\mathrm{NH}_{3}$ emissions (t) for Los Lagos and Los Ríos Regions, Chile, 2007.

The $87 \%$ of $\mathrm{NH}_{3}$ emissions came from grazing areas, $9 \%$ from livestock housing, $3 \%$ was from waste storage, and $2 \%$ from the application of this waste to the land. The difference of the total amount of ammonia estimated in the period of study was only $109 \mathrm{t} \mathrm{NH}_{3}-\mathrm{N}$, this could be a direct consequence that registered cattle number did not present a remarkable increase in the years evaluated according to the National Survey for Agriculture and Forestry data (INE, 1997; 2007). Also, the results show that there were increases in $\mathrm{NH}_{3}-\mathrm{N}$ emissions of all types of cattle, because of increases in the herd over the study period, being mainly in cows, heifers and steers.

The highest increases in $\mathrm{NH}_{3}-\mathrm{N}$ emission in accordance with livestock class were found in cattle, followed by sheep and camelids, while the largest emission reductions can be found in equines, followed by pigs and goats. For the main period of study (1997 to 2007), cattle represented more than $85 \%$ of the total $\mathrm{NH}_{3}-\mathrm{N}$ emissions in the area, where nearly $59 \%$ of this can be attributed mostly to dairy cows and $16 \%$ to dairy heifers (Figure 3 ). These results are similar to those reported by Hyde et al . (2003), Misselbrook et al. (2007), and Reidy et al. (2007), who identified in their inventories that cattle production is the largest source of $\mathrm{NH}_{3}-\mathrm{N}$ emission besides other gases such as methane $\left(\mathrm{CH}_{4}\right)$ and nitrous oxide $\left(\mathrm{N}_{2} \mathrm{O}\right)$.

Using the cattle emission estimate for the total study area, was established an emission equivalent to $6 \mathrm{~kg} \mathrm{NH}_{3}-\mathrm{N}$ dairy $\mathrm{cow}^{-1} \mathrm{yr}^{-1}$, while in the inventory carried out for UK, Misselbrook et al. (2007) estimated losses equivalent to $26 \mathrm{~kg} \mathrm{NH}_{3}-\mathrm{N}$ dairy cow ${ }^{-1} \mathrm{yr}^{-1}$. This could be the result of the low intensification of animal production systems in southern Chile, since most livestock is handled in pasture-based systems, with limited housing periods (Salazar et al., 2003); which explains the high proportion of estimated emissions over grazing in southern Chile (approximately 87\% for 1997 and 2007), compared with 


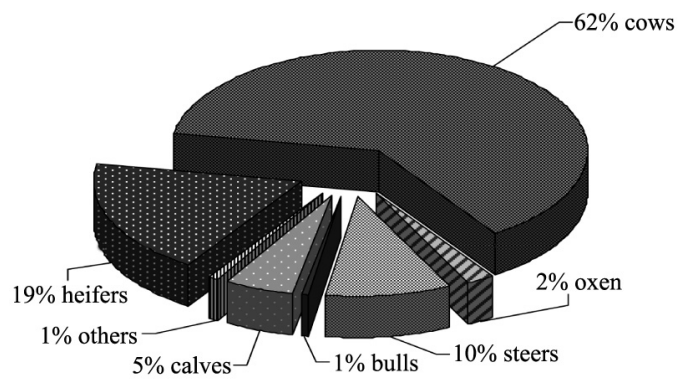

Figure 3. Percentage of contribution from different cattle types to total ammonia emission in Los Lagos and Los Ríos Regions, Chile, 2007.

the low proportion of those estimated UK (12\% in 2006). Additionally, southern Chile is estimated to have low $\mathrm{N}$ fertilizer inputs in grasslands, and also low herd number per agricultural area (according to Anrique, 2008). Both factors are directly related to the magnitude of $\mathrm{NH}_{3}-\mathrm{N}$ emission according to Diaz et al . (2003) and Sommer et al. (2004).

The current total $\mathrm{NH}_{3}-\mathrm{N}$ emission estimation of the two regions where most of the cattle production is concentrated ( $\approx 6 \mathrm{kt} \mathrm{NH}_{3}-\mathrm{N} \mathrm{yr}^{-1}$; Figures 1 and 2$)$ is low when compared with those values reported in whole countries like Denmark, South Korea, Ireland, UK and Switzerland whose emissions fluctuates between 41 to 263 kt $\mathrm{NH}_{3}-\mathrm{N} \mathrm{yr}^{-1}$ (Hutchings et al., 2001; Lee and Park, 2002; Hyde et al., 2003; Misselbrook et al., 2007; Reidy et al., 2007). However, low $\mathrm{N}$ could have significant impacts on the receiving environment; natural resources as pristine forests, fresh soils, or water bodies such as those find in southern Chile could be impacted with extra $\mathrm{N}$ inputs, because this element is almost always a restrict macronutrient in this forest (e.g., Oyarzún et al., 2002; Godoy et al., 2003). In addition, further studies of the overall cycle of $\mathrm{NH}_{3}$, its transformation to form fine particles through the atmosphere and its deposition are required for the area of the present study in order to predict the potential impacts into the regional environment.

Inputs from goats, sheep, pigs, horses and camelids represent only $13 \%$ to $15 \%$ of the total $\mathrm{NH}_{3}-\mathrm{N}$ emissions of the study area (Table 2). This fact can be explained because the main productive systems for these animal types are not concentrated in this area, but are distributed throughout the country. Main productive areas for pigs are concentrated in the central area, sheep in the Patagonia area, and goats and camelids in the north of Chile (INE, 2007). For those territories highest $\mathrm{NH}_{3}-\mathrm{N}$ emission values are expected from these animal types, and local environmental impacts of its intensive production systems (i.e. pigs) could be considered more important than those extensive sources (e.g. grazing cattle).

Our estimations for the future indicate that if the current conditions are maintained over time, and without implementing any abatement strategies, goats, pigs and horses would decrease their emissions, presenting a reduction of $60 \%, 35 \%$ and $35 \%$, respectively, for 2027 regarding the base year emission (Table 2). This decrease is based on the negative growth rate, which is caused by

Table 2. Total ammonia emission estimations from the livestock types in Los Lagos and Los Ríos Regions, Chile, for different years.

\begin{tabular}{|c|c|c|c|c|c|c|}
\hline \multirow{2}{*}{\multicolumn{2}{|c|}{ Livestock class }} & \multicolumn{2}{|c|}{ Real data } & \multicolumn{2}{|c|}{ Projections } & \multirow[b]{2}{*}{ Trend } \\
\hline & & 1997 & 2007 & 2017 & 2027 & \\
\hline \multirow[t]{8}{*}{ Cattle } & Cows & 3240 & 3376 & 3518 & 3666 & \multirow{8}{*}{ Increasing } \\
\hline & Heifers & 966 & 1006 & 1048 & 1091 & \\
\hline & Calves & 263 & 273 & 285 & 297 & \\
\hline & Steers & 499 & 519 & 540 & 562 & \\
\hline & Bulls & 34 & 35 & 37 & 38 & \\
\hline & Oxen & 117 & 123 & 129 & 135 & \\
\hline & Others & 42 & 44 & 46 & 48 & \\
\hline & Total for the class & 5160 & 5377 & 5602 & 5837 & \\
\hline Sheep & & 78 & 85 & 93 & 101 & Increasing \\
\hline Goats & & 4.5 & 3.4 & 2.5 & 1.8 & Decreasing \\
\hline Pigs & & 398 & 344 & 297 & 257 & Decreasing \\
\hline Equines & & 456 & 395 & 343 & 297 & Decreasing \\
\hline Camelids & & 0.7 & 2.3 & 7.2 & 23 & Increasing \\
\hline & Total & 6097 & 6206 & 6344 & 6516 & Increasing \\
\hline
\end{tabular}


the decline in the number of herd. In addition, a further decline could occur by changes in market conditions and other technical advances implemented in production systems. However, this reduction can be offset by the $13 \%$ increase in those derivated from cattle, and also for the $29 \%$ and more than $100 \%$ increase expected from sheep and camelids (Table 2).

\section{Suggestions for improving the ammonia emission inventory}

Producing this study, it was apparent that little published data like statistical information characterizing the national and regional production systems exist in relation to livestock numbers, animal type and age, and management practices such as length of periods of grazing and housing and waste handling chain (type, produced quantity, $\mathrm{N}$ content, storage systems, length of storage period and spreading techniques and dates of application). This issue is reflected in the fact that few studies about characterization of diary production systems and their effluent have been carried out in the regions under study (e.g. Anrique, 2008; 1999; Salazar et al., 2003). For that reason in order to improve the ammonia emission estimations in future inventories, the development of reliable national and regional data sets through the establishment of a high quality management survey and focused statistical agricultural information will be required.

Specifically this paper highlights the need to cover information deficits like specific emission factors for Chile, especially in the Los Lagos and Los Ríos Regions, where livestock production systems and management practices could differ from those reported elsewhere. In regard of this issue, more research on $\mathrm{NH}_{3}-\mathrm{N}$ losses from different climatic and soil conditions will be required to obtain a realistic and representative emission inventory of this territory (Table 1). Also, it is necessary to improve the spatial resolution of the inventory output (Figures 1 and 2), trying to report not a single value for an entire area because agricultural productive activities are more intense in some specific points of the territory. Consequently, inventories could overestimate emissions in non agricultural areas and underestimate emissions in the very productive ones.

The use of inventories data with poor resolution could be inadequate in the development of atmospheric chemistry models of dispersion and deposition of this pollutant. In addition, it is necessary to improve the temporal resolution, trying not only to report annual averages, principally because animal agricultural activities are seasonal and its intensity varies through the year and $\mathrm{NH}_{3}-\mathrm{N}$ fluctuates accordingly. This could result in the overestimation or underestimation of the emissions in different seasons of the year. Furthermore it is advisable to incorporate emission data from the fertilizers application.

Improving these factors will not only be useful for $\mathrm{NH}_{3}-\mathrm{N}$ emissions but for $\mathrm{N}_{2} \mathrm{O}$ and $\mathrm{CH}_{4}$ agricultural inventories too. Data generated on future emission inventories will facilitate the identification of possible mitigation practices while increasing the understanding about some deleterious effects of this sort of emissions on climate change. Then inventories constitute practical tools for government to define its position in terms of potential incorporation to international treaties and protocols relating to this subject (Giles, 2002).

\section{Measures for the management of ammonia emissions}

Reduced N emissions from animal agricultural operations will not only be important because of the environmental effects associated, but also because of the economic gains of more efficient use of agricultural supplies (Kurvits and Marta, 1998). Control strategies to reduce $\mathrm{N}$ emissions through $\mathrm{NH}_{3}-\mathrm{N}$ volatilization in Los Lagos and Los Ríos Regions can include essentially changes in farm management practices such as: type and duration of livestock grazing/housing; strategies for pasture nutrient management like minimize the amount of $\mathrm{N}$ surplus given to soils in form of organic or inorganic fertilizers; techniques that slow decomposition, fermentation, and volatilization processes in manure during livestock housing or waste storage; the use of better land spreading techniques for the manure application to soil such as band spreading, trailing shoe or injection; improve feeding strategies like balanced amino acid diets; and energy on feeds (Kurvits and Marta, 1998; Hutchings et al., 2001; Diaz et al., 2003; Hyde et al., 2003).

However the use of abatement techniques and their efficiency depends upon several factors and will require the verification under Chilean conditions. Nevertheless with these and other actions, there is a considerable potential to reduce $\mathrm{NH}_{3}-\mathrm{N}$ emissions at a regional scale. Also will be important to consider all nutrient losses on a system approach because it has been evaluated that minimizing $\mathrm{N}$ losses from step one (e.g. $\mathrm{NH}_{3}$ losses) could affect $\mathrm{N}$ losses due to $\mathrm{N}$ leaching or $\mathrm{N}_{2} \mathrm{O}$ emissions (Webb et al., 2006).

\section{CONCLUSIONS}

Data analyzed in the inventory showed that animal production produced $6097 \mathrm{t} \mathrm{NH}_{3}-\mathrm{N}$ in 1997 and $6206 \mathrm{t}$ $\mathrm{NH}_{3}-\mathrm{N}$ during 2007 in the area of study. It was estimated that Los Lagos Region is the mayor source of $\mathrm{NH}_{3}(63 \%)$. Also, districts of Río Bueno and Osorno were identified as the territories with higher ammonia emissions $(\approx 10 \%$ and $6 \%$ of the total estimated, respectively). Cattle, especially dairy cows, represent the largest livestock ammonia 
source (85-87\%) and grazing was identified as the main source of emission in terms of farm management (87\%). Projection suggests that emission could increase up to 6344 and $6516 \mathrm{t} \mathrm{NH}_{3}-\mathrm{N}$ for 2017 and 2027, respectively.

Emission estimates and projections do not show a clear indication that the area of study requires urgent implementation of abatement strategies to enable emission reduction. However, a change in farm management practices such a high use of urea fertilizer or more intensive surface cattle slurry application could impact on $\mathrm{N}$ losses by $\mathrm{NH}_{3}$ volatilization, and abatement practices will be required. Also, there is a need to take into account al forms of $\mathrm{N}$ emission from agricultural sources in the Los Lagos and Los Ríos Regions. To achieve that, inventories ought to be more realistic, detailed and robust, basing its estimations on integral approaches, which will allow us to get accurate assessment of the $\mathrm{NH}_{3}$ and other pollutants abatement options.

\section{RESUMEN}

Inventario de emisiones de amoníaco de la producción pecuaria de las Regiones de Los Lagos y de Los Ríos, Chile. Este artículo presenta el primer inventario de emisiones de amoníaco de la producción pecuaria de las Regiones de Los Lagos y Los Ríos de Chile, porque esta área concentra la producción chilena de ganado bovino. Este estudio tuvo como objetivos cuantificar las pérdidas de $\mathrm{N}$ por volatilización de amoníaco emitidas desde la producción animal en estas regiones del país, y proveer su representación espacial identificando las principales fuentes de emisión. Los cálculos fueron realizados para 1997 y 2007; y desde el año base se proyectaron emisiones para los años 2017 y 2027. Las emisiones calculadas fueron 6097 y $6206 \mathrm{t} \mathrm{NH}_{3}-\mathrm{N}$ para 1997 y 2007, respectivamente. Las principales fuentes de emisión fueron los bovinos con más del $85 \%$ de las emisiones, seguido por equinos y porcinos. Prácticas de manejo de las explotaciones pecuarias como el pastoreo, la estabulación de ganado, el almacenamiento y la aplicación de desechos aportaron el $87 \%, 9 \%, 3 \%$ y $2 \%$, respectivamente, del total de las emisiones anuales. Las proyecciones sugieren que las emisiones pueden alcanzar las 6344 y $6516 \mathrm{t} \mathrm{NH}_{3}-\mathrm{N}$ para el 2017 y 2027, respectivamente. Estas emisiones son mucho menores que las reportadas por algunos países europeos desarrollados. Sin embargo, la intensificación de los sistemas productivos ganaderos puede conllevar al aumento en las emisiones de amoníaco, las cuales pueden provocar un impacto en los bosques templados del sur de Chile caracterizados por bajos flujos de nutrientes.

Palabras clave: amoníaco, inventario, producción animal, emisión.

\section{LITERATURE CITED}

Alfaro, M., y F. Salazar. 2005. Ganadería y contaminación difusa, implicancias para el Sur de Chile. Agric. Téc. (Chile) 65:330-340

Anrique, R. 1999. Caracterización del Chile lechero. p. 114-157. In Latrille, L. (ed.) Producción animal. Universidad Austral de Chile, Valdivia, Chile.

Anrique, R. 2008. Producción de leche en pastoreo: antecedentes de la situación chilena. Serie Simposios y Compendios 14:71-86. Sociedad Chilena de Producción Animal (SOCHIPA), Santiago, Chile.

Arcview. 2007. Version 3.2. Environmental Systems Research Institute, Inc. (ESRI), Redlands, California, USA.

Asman, W., M. Sutton, and J. Schjorring. 1998. Ammonia: Emission atmospheric transport and deposition. New Phytol. 139:27-48.

Bouwman, A., D. Lee, W. Asman, F. Dentener, K. VanderHoek, and J. Olivier. 1997. A global highresolution emission inventory for ammonia. Global Biogeochem. Cycles 11:561-587.

Diaz, M., R. Strader, and C. Davidson. 2003. An ammonia emission inventory for fertilizer application in the United States. Atmos. Environ. 37:2539-2550.

Eckard, R., D. Chen, R. White, and D. Chapman. 2003. Gaseous nitrogen loss from temperate perennial grass and clover dairy pastures in south-eastern Australia. Aust. J. Agric. Res. 54:561-570.

Excel. 2007. Version 2007. Microsoft Corporation, Redmond, Washington, USA.

Giles, R. 2002. Un nuevo paso en la protección internacional de la atmósfera: el protocolo para la disminución de la acidificación, la eutrofización y el ozono superficial de 1999. Derecho y Conocimiento 1:63-75. ISSN 1578-8202.

Godoy, R., L. Paulino, C. Oyarzún, and P. Boeckx. 2003. Atmospheric $\mathrm{N}$ deposition in central and southern Chile. An overview. Gayana Bot. 60:47-53.

Hutchings, N., S. Sommer, J. Andersen, and W. Asman. 2001. A detailed ammonia emission inventory of Denmark. Atmos. Environ. 35:1959-1968.

Hyde, B., O. Carton, P. O'Toole, and T. Misselbrook. 2003. A new inventory of ammonia emissions from Irish agriculture. Atmos. Environ. 37:55-62.

INE. 1997. Resultados preliminares del VI Censo Nacional Agropecuario y Forestal. 443 p. Instituto Nacional de Estadísticas (INE). Impresos Universitarios, Santiago, Chile. 
INE. 2007. Resultados preliminares del VII Censo Nacional Agropecuario y Forestal. Instituto Nacional de Estadística. Available at http://www.ine.cl/canales/ chile_estadistico/censos_agropecuarios/xls/2007/12_ rev.xls (accessed November 2007).

Jones, J., N. Carmichael, C. Wathes, R. White, and R. Jones. 2000. The effects of acute simultaneous exposure to ammonia on the detection of buried odourized food by pigs. Appl. Anim. Behav. Sci. 65:305-319.

Kurvits, T., and T. Marta. 1998. Agricultural $\mathrm{NH}_{3}$ and $\mathrm{NO}_{x}$ emissions in Canada. Environ. Pollut. 102:187-194.

Lee, Y., and S. Park. 2002. Estimation of ammonia emission in South Korea. Water Air Soil Pollut. 135:23-37.

Misselbrook, T., T. Van der Weerden, B. Pain, S. Jarvis, B. Chambers, K. Smith, et al. 2000. Ammonia emission factors for UK agriculture. Atmos. Environ. 34:871-880.

Misselbrook, T., D. Chadwick, B. Chambers, K. Smith, J. Williams, and T. Demmers. 2007. Inventory of ammonia emissions from UK agriculture 2006. 35 p. Inventory Submission Report. Department for Environment, Food and Rural Affairs, London, UK.
Oyarzún, C., R. Godoy, and S. Leiva. 2002. Atmospheric deposition of nitrogen in a transect from the Central Valley to Cordillera de Los Andes, south-central Chile. Rev. Chil. Hist. Nat. 75(1):233-243.

Reidy, B., B. Rhim, and H. Menzi. 2007. A new Swiss inventory of ammonia emissions from agriculture based on a survey on farm and manure management and farm-specific model calculations. Atmos. Environ. 42:3266-3276.

Salazar, F., J. Dumont, M. Santana, B. Pain, D. Chadwick, y E. Owen. 2003. Prospección del manejo y utilización de efluentes de lecherías en el sur de Chile. Arch. Med. Vet. 35(2):215-225.

Schmidt-Nielsen, B., K. Schmidt-Nielsen, T. Houpt, and S. Jarnum. 1957. Urea excretion in the camel. Am. J. Physiol. 188:477-484.

Sommer, S., J. Schjoerring, and O. Denmead. 2004. Ammonia emission from mineral fertilizers and fertilized crops. Adv. Agron. 82:558-622.

Webb, J., M. Ryan, S. Anthony, A. Brewer, J. Laws, M. Aller, and T. Misselbrook. 2006. Cost-effective means of reducing ammonia emission from UK agriculture using the NARSES model. Atmos. Environ. 40:72227233 . 